\title{
Solid Waste Management Issues in Hyderabad City
}

\author{
ALI RAZA KHOSO*, AFTAB HAMEED MEMON**, ASHFAQUE AHMED PATHAN* AND \\ MUHAMMAD AKRAM AKHUND* \\ RECEIVED ON 30.10.2017 ACCEPTED ON 12.02.2018
}

\begin{abstract}
Solid waste is a great threat not only to the economy of any country but for the environment too. The public through various sources generate tons of solid waste regularly. In the era of globalization, one of the rising issues of developing and under developed countries is handling such huge masses of solid waste. Hyderabad is the $2^{\text {nd }}$ largest city of Sindh and $6^{\text {th }}$ in Pakistan. Unfortunately, it does not poses proper solid waste management system right from collection up to its proper disposal. Most of those uncollected wastage poses a highrisk to the public through blockage of drains and formation of stagnant ponds which provide a breeding ground for flies and mosquitoes with a high risk of diseases. The public role and awareness can reduce this enormous load from Government. This research aims to uncover the reasons for solid waste generation in Hyderabad city. For data collection, various dumping sites in the city have been visited. Interviews were conducted with municipal officers of city for more precise data and possible causes of waste generation. Finally, a questionnaire survey has been conducted to list out top most significant causes of poor work management in the city. The data was analyzed in SPSS 24.0 with the help of average index technique. From the analysis of data, the top critical causes have been identified for Hyderabad city and discussed with the field expert for their possible solution.
\end{abstract}

Key Words: Solid Waste Management, Hyderabad City, Waste Sources, Dumping Sites.

\section{INTRODUCTION}

$\mathrm{I}$

$\mathrm{n}$ the era of globalization, in some aspects yet

Pakistan is dealing with several uneven changes

regarding education, politics and policymaking. Beside this, another raising matter of concerns is a high quantum generation of solid waste. Increasing population, industrialization, urbanization and change in consumption patterns have a severe impact in raising the solid waste countrywide [1]. This has exerted adverse effects on environmental conditions of urban areas [2]. This can be visualized as results of non-serious attitude of citizens and lack of education, as large heaps of garbage lying in a disorganized manner in every nook and corner in several areas of cities can be experienced.

Pakistan has recorded continuous increase in the population where it is reported that over 200 million people are living there [3]. With this increase in population, generation of solid waste is also increased. As reported by [4] waste generation in Pakistan is around 0.23-0.61 $\mathrm{kg} /$ capita/day and a total of approximately 59,000 Tons

Authors E-Mail: (aliraza.khoso@faculty.muet.edu.pk, aftabm78@gmail.com, ashfaque.pathan@faculty.muet.edu.pk, akhund42@gmail.com) * Department of Civil Engineering, Mehran University of Engineering \& Technology, Jamshoro. ** Department of Civil Engineering, Quaid-e-Awam University of Engineering, Science \& Technology, Nawabshah.

This is an open access article published by Mehran University Research Journal of Engineering and Technology, Jamshoro under the CC by 4.0 International License. 
every day. In Pakistan municipal governments are usually responsible agency for solid waste collection and disposal, but the magnitude of the problem is well beyond the ability of any municipal government. TMA (Tehsil Municipal Administration) is responsible for the collection, transportation and disposal, but the current situation is becoming worst. They are unable to cope with continuously increasing wastage volume because of lack of rules, regulations, lack of fundraising, lack of self-awareness, lack of management and expertise and last but not the least due to lack of collection vehicles, equipment \& recycling technology [5].

Solid waste is an unavoidable by-product of most anthropogenic activities. Paper, packing material, polythene bags, metal, plastic, food waste, e-waste, glass and packing materials are the major contributor to generating Municipal Solid Waste. In most of the countries like in low and average revenue generation, there are various social as well as environmental severe threats due to the mismanagement of solid waste [6].

This emphasis on the need for proper solid waste management system in the city otherwise it may cause many negative effects which could create certain problems for the community and would reduce social values. Unmanaged solid waste increases the number of flies and mosquitoes which are very dangerous and can cause malaria and other infections which are a threat to public health. Hence, it is imperative to realize the importance of solid waste management and enhance the significance of adequate waste disposal in local public. Being developing country Pakistan faces several problems including environmental hazards. Rapid annual population growth and impressive GDP growth has an enormous effect on country's natural sources and increases levels of pollution [7]. It is unable to handle the continuously rising waste volume because of lack of; rules \& regulations, fund raising, self-awareness, management and expertise and collection vehicles, equipment and recycling technology [5].

In Hyderabad city the domestic waste has not been carried out in a sufficient manner in regard to transportation up to disposal due to several social and financial issues. Hence those garbage bins become the Institute for developing infections and breeding of several species, demolishing the value of the area in several aspects. Crude open dumping of wastage is the most commonly used practice spread all over the Pakistan and these dumpsites are set alight for reducing the volume of accumulating waste. Solid waste is an unavoidable by-product of most anthropogenic activities. Paper, packing material, polythene bags, metal, plastic, food waste, e-waste, glass and packing materials are the major contributor to generating Municipal Solid Waste. In most of the countries like in low and average revenue generation, there are various social as well as environmental severe threats due to the mismanagement of solid waste [6].

The research aims to study the current black side of wastage disposal in Hyderabad city and to provide the solutions for those mishaps in systems. Furthermore, it covers the solid waste management system of the city and also determines the sources and reasons of solid waste management. For practical and theoretical approach different sources of solid waste in Hyderabad have been visited. Interviews were conducted with municipal officers of the city for data collection of waste and possible solutions. Interviews with experts were also the part of the research.

\section{LITERATURE REVIEW}

The environment friendly management of municipal solid waste is a global challenge [8]. However, many municipalities fail in controlling the management of solid 
waste because of lack of institutional, regulatory, financial, technical, and public participation [9]. Few administrative entities have framed strategies for environmental protection but unfortunately these rules are mainly adopted in capital cities only [10]. Yet, in most of the cities, open space areas are utilized for dumping [11]. Reduction of this issue is a great challenge for developing countries like Pakistan. The public can play the major role in reduction and overall management of this issue. In Pakistan, it is reported that solid waste generated is near about 64,000 tons per day [12]. It seems that there is lack of awareness regarding the issue of solid waste management whereas the prime and effective solid waste management is only possible with an attitude of the public [13]. Japan is reported as successful in reducing solid waste by implementing the concept of shared responsibility where Public detach the waste into combustibles, non-combustibles and recyclables before dumping. Municipalities gather waste paper, glass, metal, etc. as recyclables to recycle while other wastes which include plastics, glass, metal etc. are crumpled before recycling [14].

Keeping in the view the current severity of problems due to solid waste, Pakistan is now more focusing on formulating rules and regulations. Also it is actively involved in finding donor agencies such as World Bank. But unfortunately, this practice is again not effective as environmental institutions, laws, and other initiatives have not proved successful in resolving the concerned matters [15]. In such situations, the policy of sharing practices i.e. public to separate waste and approach directly to the concerned authority seems to be a better decision. Involvement of community and private sector through NGOs will be helpful in increasing efficiency of solid waste management [11].

Performance of solid waste management is directly affected by the community and the policies of the government. In many of the municipalities of Pakistan, the system for collection and disposal of the waste is not proper or there is a lack of operations. Hence, this drew the attention of the researchers to study the system and issues related to solid waste management in Pakistani municipalities. However, the focus of this paper is the solid waste management in the city of Hyderabad, Sindh, Pakistan.

\section{RESEARCH METHODOLOGY}

Data collection in this study involved views of the field personnel's, municipal corporation officers and waste management staff through structured questionnaire and instructed interviews. Also, various waste disposal places within the city were considered for a site visit. Total 90 questionnaires were distributed among targeted respondents, where only 63 completed questionnaire forms were received and considered valid for analysis. The questionnaire focused on uncovering the reasons of solid waste generation where investigated level of importance of each reason was investigated. Respondents were asked to give feedback for each reason listed in the questionnaire used the scale as $X_{1}=$ Not Important; $X_{2}=$ Slightly Important; $X_{3}=$ Moderately Important; $X_{4}=$ Very Important; $X_{5}=$ Extremely Important. Assessment of level of significance was done using on AI (Average Index) method calculated based on frequency calculated with the help of statistical software SPSS. AI value was calculated based on following formula as adopted from [16].

$\mathrm{AI}=\frac{\sum\left(1 \mathrm{X}_{1}+2 \mathrm{X}_{2}+3 \mathrm{X}_{3}+4 \mathrm{X}_{4}+5 \mathrm{X}_{5}\right)}{\sum\left(\mathrm{X}_{1}+\mathrm{X}_{2}+\mathrm{X}_{3}+\mathrm{X}_{4}+\mathrm{X}_{5}\right)}$

For site visits, total four disposal sites from the areas of Latifabad and Qasimabad in Hyderabad were selected. In survey and interviews during site visits, the personnel were asked about the whole procedure from disposing of waste at the site up to its utilization. Several meetings \& interviews were conducted with the experts in the relevant

Mehran University Research Journal of Engineering \& Technology, Volume 37, No. 3, July, 2018 [p-ISSN: 0254-7821, e-ISSN: 2413-7219] 
field, in order to highlight the role of the public in solid waste management.

\section{RESULTS AND DISCUSSION}

Four waste disposal sites were selected and visited in order to observe the issues regarding solid waste management practiced in Hyderabad as well as understanding sources and types of waste disposedoff.

\subsection{Issues Regarding Solid Waste System in Hyderabad}

In Hyderabad, it is observed that solid waste management is very poor. This inefficiency of the system is because of several issues which are discussed below:

\subsubsection{Equipment}

Equipment facilities mostly provided on site do not fit with the site condition. Most of the machines are not properly operated by local labor. Also there is a shortage of spare parts in the local vicinity. Basic facilities of local solid waste management are inappropriate. It was due to the large height of the waste collector units. It is difficult for children to throw waste into the collector due to which partial waste is always dropped on the ground. Further, the machinery which is brought is without addressing the local culture and conditions. Many times, there is a problem of spare parts and this hinders the effectiveness by causing a problem in maintenance and repair.

\subsubsection{Operations and Maintenance}

By visiting several areas and disposal sites, it was found that many of the times collection of waste is delayed or cancelled because of several basic issues such as shortage of fuel, lack of funds, or wasted time as collection vehicles wait their turn for fuel in a petrol station. Often the waste collection crew does not consider areas of high waste generation as these areas are far from their approach. Usually, the collection begins at the points nearest to the dispatch station and mostly the containers are placed near a residential area. Before they reach to the remote areas of the city, it is nearly the end of the working hours. This procedure results in overflowing bins and containers with their attendant health risks, blockage of roads, odor nuisance, and filthy environment. Figs. 1-4 highlights the solid waste at different sites of the city.

No matter how efficient a solid waste system adopted but it will fail to achieve the required efficiency if there is no effective operation and maintenance [9]. Occasionally in the city, the sanitary landfill equipment breaks down and then landfill is operated as an open dumping site because the waste is no longer compacted and covered properly. The dumping sites are not well maintained after they were developed. Lack of grading and soil cover enables rain water to infiltrate refuse and produce such bacteria that contaminates groundwater reservoirs.

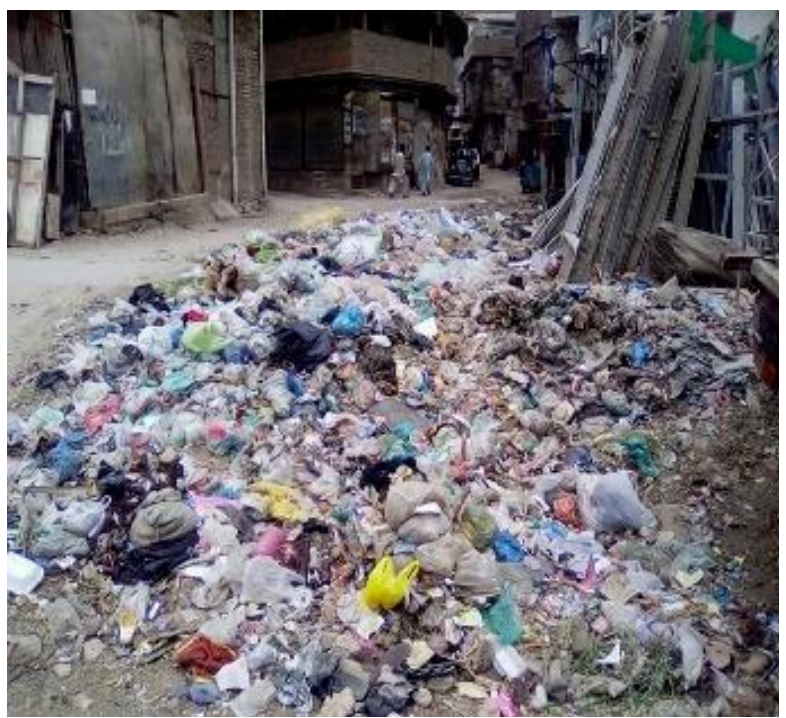

FIG. 1. LATIFABAD UNIT -6, DUMPING SITE ON ROAD

Mehran University Research Journal of Engineering \& Technology, Volume 37, No. 3, July, 2018 [p-ISSN: 0254-7821, e-ISSN: 2413-7219] 


\subsubsection{Waste Collection and Storage}

For roads and streets cleaning and gathering the waste, there is no proper schedule for the entire city. Somewhere this process is regularly done but a complete discrimination is found for other less

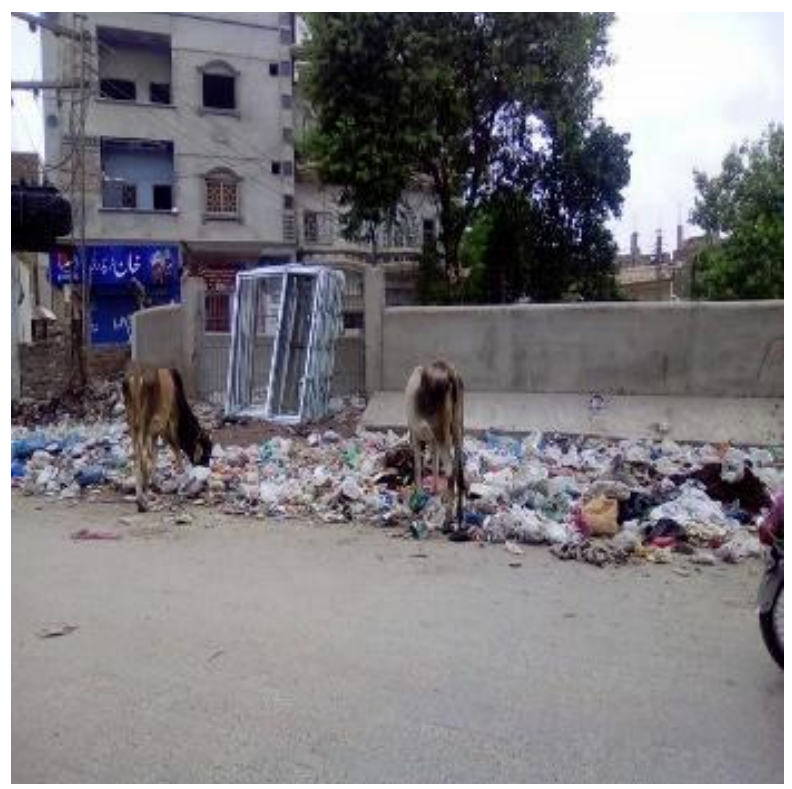

FIG. 2. AIRPORT ROAD, LATIFABAD

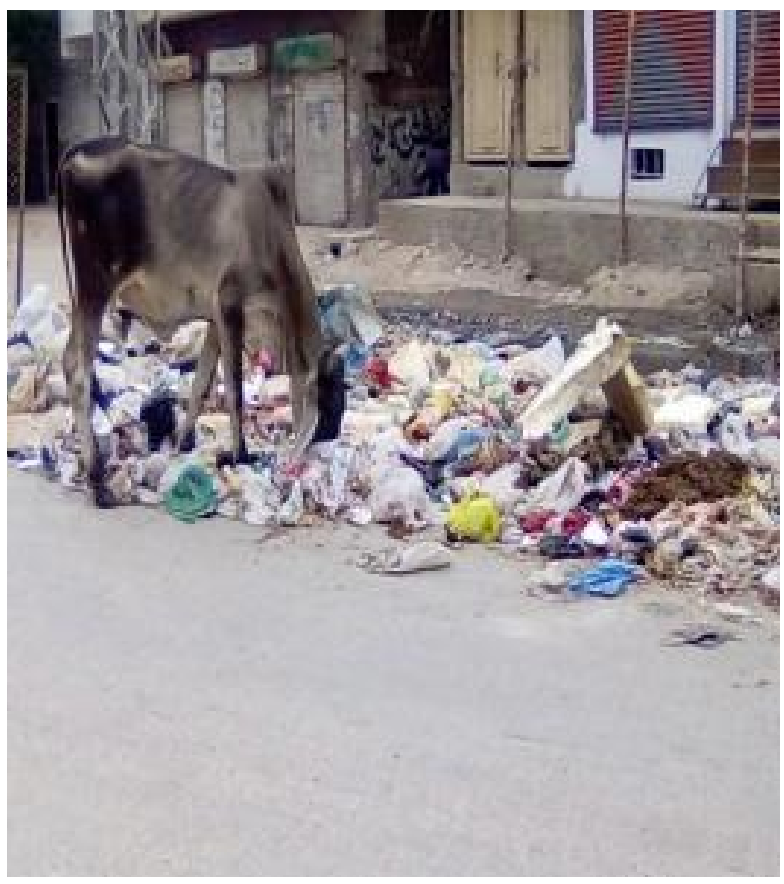

FIG. 3. LATIFABAD UNIT-6, THE POOR STATE OF WASTE AT MAIN ROAD privileged areas. Mostly in the low-income areas, the waste is thrown on streets and along the roads. It was also noticed that the dumping and storage facilities were not enclosed. The public is forced to dump the waste in open space such as drains, open container etc. This is resulting in the unhygienic environment, foul smell and odor, which ultimately welcome flies and other vectors. In many areas of the city, the quantity of bins is even not sufficient or the bins are not available, and the public has no option other than to throw the dump in streets, roads etc.

\subsubsection{Waste Transferring}

One of the major issues regarding solid waste management aspects in Hyderabad city is the transferring after being collected to the designated place. A study highlighted that the generation of solid waste is about 1600 tons with a rate of $0.6-0.8 \mathrm{~kg} / \mathrm{capita} / \mathrm{day}$ [17]. To collect this huge quantum of waste, the local government. has no facilities in the form of vehicles to

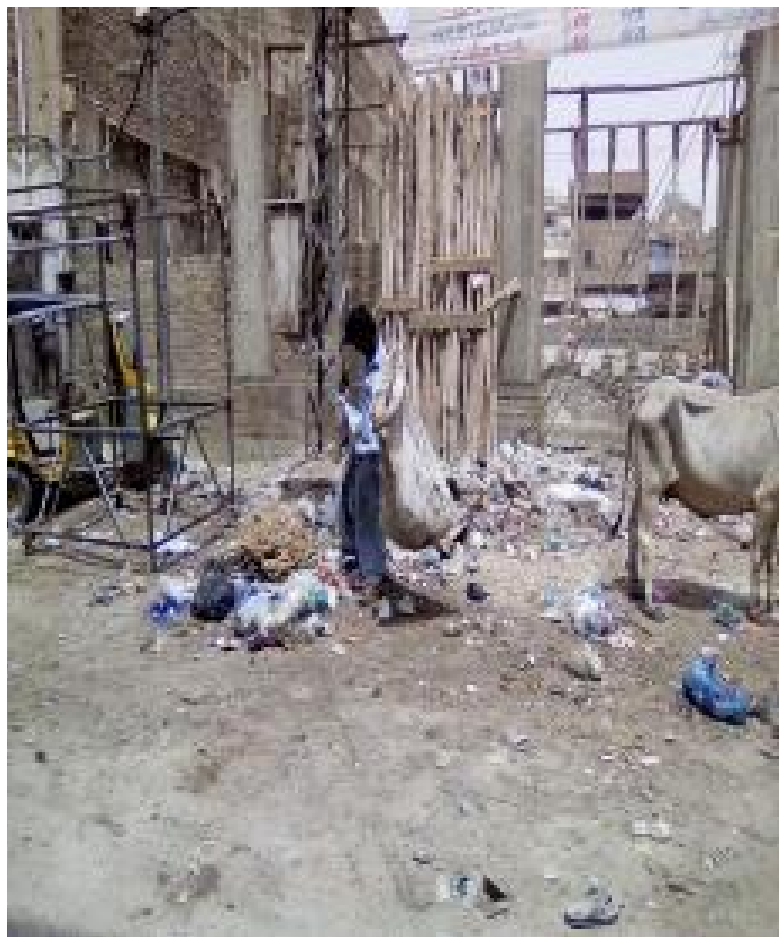

FIG. 4. WASTE DISPOSAL SITE AT LATIFABAD UNIT-12

Mehran University Research Journal of Engineering \& Technology, Volume 37, No. 3, July, 2018 [p-ISSN: 0254-7821, e-ISSN: 2413-7219] 
transfer it. Further, it was noticed that vehicles used for collection and transfer are outdated and insufficient in number to cope with the need of shifting whole solid waste quantity. Also, there are no extra vehicle on standby to utilize in case of emergency or if any vehicle undergoes failure. Besides this, for the vehicles, there is no any systematic route plan available or designed by the local government.

\subsubsection{Waste Disposal and Treatment}

Normally the waste is disposed of on uncontrolled non engineered landfills. Also, there is no control on the entry of rag pickers who carryout rag picking in a haphazard and hazardous way. The leachate generated is not collected properly or treated before being discharged into water bodies. This increases contamination in the water. In order to reduce this contamination, it is compulsory that engineered landfills with proper leachate collection, extraction systems and odorous gas collection with extraction systems should be adopted. A research work indicated that drains and piped outlets in Hyderabad discharge over 225,000 cubic meter liquid of waste every day where Darya Khan pumping station releases 96,441 cubic meters per day, Kali Mori open drain 56,376, Old Power House open drain 42, 323, Cantonment Board Hyderabad 13,944, SITE pumping station and other sources 13,500 each [18]. In controlling contamination of the water, biological treatment processes like biogas generation and anaerobic processes for methane generation can be considered for treatment which is not available.

\subsection{Sources of Disposed Solid Waste}

The sources of disposing of waste were categorized into four groups as residential, commercial, institutional and municipal service. This classification was done based on observations during site visits. Each source was contributing to different types of waste. Types of waste as identified during visits to the disposal station included cardboard, batteries, papers, wood, plastics, glasses etc. Summary of the waste found at disposal sited with respect to their source of generation is summarized in Table 1.

During the visit structured questionnaire and unstructured interview were arranged with the staff and responsible person for managing waste at the disposal sites. By analyzing 63 completed questionnaire forms collected during these visits were statistically analyzed to draw the consensus of the respondents. Target of the questionnaire and interviews were conducted to uncover the reasons for the waste generation which was disposed off at the selected sites. The results of the questionnaires obtained from $\mathrm{AI}$ method are presented in Table 2.

TABLE 1. SOURCE AND TYPES OF MUNICIPAL WASTE

\begin{tabular}{|c|c|c|}
\hline Source & Typical Waste Generators & Types of Solid Waste \\
\hline Residential & House/Apartments & $\begin{array}{c}\text { Food wastes, paper, cardboard, plastics, textiles, glass, } \\
\text { metals, ashes, special wastes (bulky items, consumer } \\
\text { electronics, batteries, oil and tires) and household } \\
\text { hazardous wastes }\end{array}$ \\
\hline Commercial & Offices, restaurants, hotels, markets and stores & $\begin{array}{l}\text { Paper, cardboard, plastics, wood, food wastes, glass, } \\
\text { metals, special wastes, hazardous wastes }\end{array}$ \\
\hline Institutional & $\begin{array}{c}\text { School, University, College, Hospitals, Prisons and } \\
\text { Government Centre }\end{array}$ & $\begin{array}{l}\text { Paper, cardboard, plastics, wood, food wastes, glass, } \\
\text { metals, special wastes, hazardous wastes }\end{array}$ \\
\hline Municipal Services & $\begin{array}{c}\text { Street Cleaning, Landscaping, Parks, Beaches and } \\
\text { Recreational Areas }\end{array}$ & $\begin{array}{l}\text { Street sweepings, landscape and tree trimmings, general } \\
\text { wastes from parks, beaches and other areas }\end{array}$ \\
\hline
\end{tabular}

Mehran University Research Journal of Engineering \& Technology, Volume 37, No. 3, July, 2018 [p-ISSN: 0254-7821, e-ISSN: 2413-7219] 
The mean of the $1^{\text {st }}$ factor has 18.90 SD (Standard Deviation). Most of the respondents i.e. 46 out of 63 marked this factor extremely important. The major reason is, increase in population is a common cause of waste generation in Hyderabad and mostly people agree with it, that is why it has the highest value of AI too. For factors from $2^{\text {nd }}$ to $6^{\text {th }}$, SD is within almost equal range, here, the majority of respondents are lying in VI (Very Important) and EI (Extremely Important). However, the minimum SD is calculated for factor high living standards. Here the respondents are lying from SI (Slightly Important) to EIEI. The major reason being the difference of opinion on this factor. As some people observe the high standards living positively, with a high level of awareness. However, others take in a different way i.e. generating a high level of waste.
From Table 2 it can be observed that increase in population is reported as the most significant reason for solid waste in Hyderabad city. Further, overall the solid waste management system in Hyderabad is very poor and not able to deal properly. Though it is difficult to control the population growth, however, there must be law and order situation and enforcement of rule by the government regarding population control throughout all over the country.

The second important factor is "Non bio degradable material usage". These materials are not easily degradable hence this is one the most cause of high magnitude of solid waste in the city. The companies should focus on this matter, and such, materials should

TABLE 2. CAUSES OF WASTE GENERATION

\begin{tabular}{|c|c|c|c|c|c|c|c|c|c|c|}
\hline No. & $\begin{array}{l}\text { Causes of } \\
\text { Wastage } \\
\text { Generation }\end{array}$ & $\begin{array}{c}\text { Not } \\
\text { Important }\end{array}$ & $\begin{array}{l}\text { Slightly } \\
\text { Important }\end{array}$ & $\begin{array}{l}\text { Moderately } \\
\text { Important }\end{array}$ & $\begin{array}{c}\text { Very } \\
\text { Important }\end{array}$ & $\begin{array}{l}\text { Extremely } \\
\text { Important }\end{array}$ & Mean & $\begin{array}{l}\text { Standard } \\
\text { Deviation }\end{array}$ & $\begin{array}{l}\text { Average } \\
\text { IndexValue }\end{array}$ & Ranking \\
\hline 1. & $\begin{array}{c}\text { Increase } \\
\text { in } \\
\text { Population }\end{array}$ & 1 & 4 & 3 & 9 & 46 & 12.6 & 18.90 & 4.5 & 1 \\
\hline 2. & $\begin{array}{c}\text { Non Bio- } \\
\text { Degradable } \\
\text { Material Usage }\end{array}$ & 1 & 3 & 11 & 18 & 30 & 12.6 & 11.84 & 4.2 & 2 \\
\hline 3. & $\begin{array}{c}\text { Lack of } \\
\text { Awareness } \\
\text { Among Public }\end{array}$ & 1 & 3 & 13 & 18 & 28 & 12.6 & 11.10 & 4.10 & 3 \\
\hline 4. & $\begin{array}{c}\text { Poor } \\
\text { Management }\end{array}$ & 1 & 3 & 13 & 18 & 28 & 12.6 & 11.04 & 4.10 & 3 \\
\hline 5. & $\begin{array}{c}\text { Defect or Bad } \\
\text { Quality from } \\
\text { Process and } \\
\text { Design }\end{array}$ & 3 & 6 & 10 & 19 & 25 & 12.6 & 9.18 & 3.90 & 4 \\
\hline 6. & $\begin{array}{c}\text { Cheap } \\
\text { Availability of } \\
\text { Shopping Bags }\end{array}$ & 3 & 6 & 10 & 19 & 25 & 12.6 & 9.18 & 3.90 & 4 \\
\hline 7. & $\begin{array}{c}\text { High } \\
\text { Living } \\
\text { Standards }\end{array}$ & 10 & 13 & 13 & 11 & 16 & 12.6 & 2.30 & 3.15 & 5 \\
\hline 8. & $\begin{array}{l}\text { Formulating } \\
\text { More than } \\
\text { Desire }\end{array}$ & 15 & 11 & 15 & 9 & 13 & 12.6 & 2.60 & 2.90 & 6 \\
\hline 9. & $\begin{array}{c}\text { Lack of Planning } \\
\text { when } \\
\text { Shopping }\end{array}$ & 11 & 22 & 14 & 7 & 9 & 12.6 & 5.85 & 2.70 & 7 \\
\hline 10. & $\begin{array}{c}\text { Limited } \\
\text { Knowledge of } \\
\text { Storage }\end{array}$ & 10 & 24 & 14 & 9 & 7 & 12.6 & 6.91 & 2.65 & 8 \\
\hline
\end{tabular}

Mehran University Research Journal of Engineering \& Technology, Volume 37, No. 3, July, 2018 [p-ISSN: 0254-7821, e-ISSN: 2413-7219] 
not be produced in high amount. Moreover, these materials should not be thrown in open dump sites, proper degradation techniques should be applied like incineration etc. Fig. 5 shows open dumping of solid waste on road.

Awareness among public is the third important cause as found by this research. The most common mistake of now a day is un-awareness regarding waste. It has been observed that public does not participate in minimizing the waste production but increase it by several means. The public could not recognize it as their duty to minimize waste and throw them on roads making the environment flirty and un-healthy and then start blaming the government. The major role is played by the public itself in this regard the need of the hour is to make them aware by various social activities.

Poor management of the higher authorities is also reported as a major cause and placed at $3^{\text {rd }}$ rank. Management in any situation is the key to success for any organization but poor management either it is a residential or a commercial project can lead to failure. In same regards the poor management of restaurants, commercial areas and construction work lead up to increase in waste production which can be minimized by developing a proper management plan for each organization.

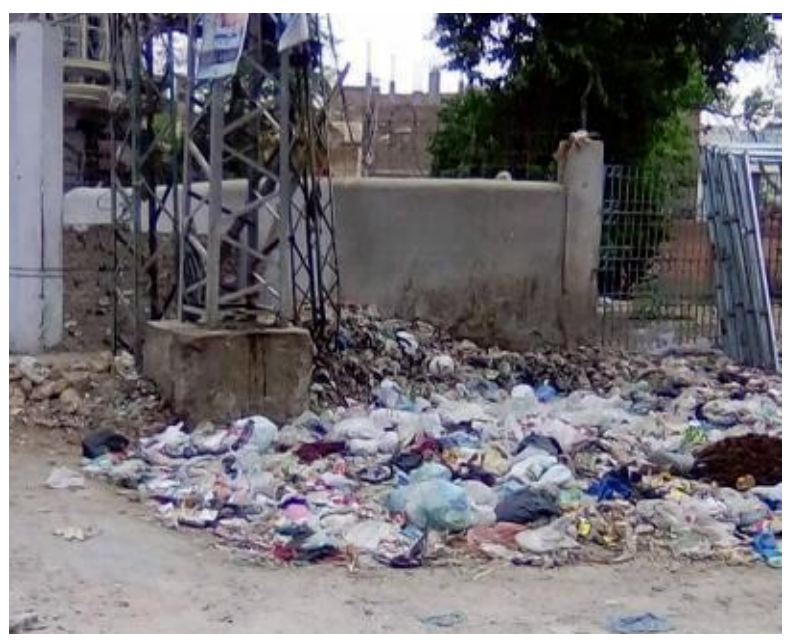

FIG. 5. OPEN DUMPING OF SOLID WASTE BY COMMUNITY ON ROAD
Defect or bad quality from process and design is also a major cause of waste generation. Poorly designed product or lack of good manufacturing instructions or training can cause reworks which cause bad quality products, customer low rating and products returns which increase waste.

Another cause of waste as identified is cheap availability of shopping bags. In the present era we can experience that most of our waste is consist of plastic bags (shopping bags), because they are cheaply available and any one can buy them on very low price, it must be reduced up to the maximum level. Instead of these bags, cloth made bags must be used so that they can be reused. According to the study of "state of Pakistan's economy", as the living standard rise, the waste generation increase because of living standards and wealth and luxurious life. This is also one of the important cause in Hyderabad city. High standard population in the city is responsible for high magnitude shopping; food etc. resulting in huge amount of solid waste.

It is common practice in houses that food is prepared more than desire, hence resulting in waste. On the other hand, in a restaurant or hotels, there is a lot of waste due to this reason. In Hyderabad city, due to the growing of hotels and restaurants, solid waste is at its peak. The public should be aware of the ways to reduce the waste. Also the restaurants should make a policy to manage the waste. Likewise, the waste can be separated there, thus making easy to deal with it. Also, lack or wrong planning while shopping can cause excessive buying of household or other materials. This results in expiring before usage and production of waste increase one step ahead. People in Hyderabad are mostly average or below medium class. They often do shopping in parts. This is also a major cause. 
Besides these, a limited knowledge of the ways of storing material can cause damaging of material before use i.e. correct use of container and materials to reduce waste (for example, how to preserve and use leftovers creatively). It will help the house holders specially to reduce domestic waste as it is important for Hyderabad city because most of the city is consist of a residential area.

\section{CONSCLUSION}

Being one of the major cities of Pakistan, Hyderabad city does not possess a well-developed solid waste management system. The visit at various locations of city unfolds the black side of the city in terms of its solid waste collection, transportation, dumping sites, recycling etc. The study investigates various causes of solid waste generation in Hyderabad with the help of several interviews and visits. Interviews were conducted from municipal officers, lower staff, dwellers of different areas of Hyderabad, rag pickers and shop keepers. The level of significance of causes was determined with the help of collecting data among various respondents with a questionnaire survey. The study concludes that, Increase in Population, Non bio degradable material usage, Lack of awareness among the public, poor management are few critical causes of waste generation in the city. The discussion with experts revealed that, population control including urban growth control in the city can reduce major issues. Reduction of non-bio degradable materials (like plastic bags), awareness among public, good management of various organizations can lead to the reduction of waste generation in the city.

The study through the results suggests that, there is an utter need for an efficient solid waste management system in Hyderabad. In this regard, the Local Government needs to put their efforts. The overall system from collection to its safer disposal requires special attention. Moreover, the public awareness can help the system more. The Local
Government should not only utilize the public funds on maintenance of entire system properly but also it requires to focus on arranging few programs like public meetings, seminars, workshops etc. on monthly basis. These programs would definitely aware the public, which is an important stakeholder in reduction and proper management of solid waste.

The research can further be extended to compare same work with other major cities of Pakistan and abroad. In this regard, in-depth literature can be reviewed in different countries and possible solutions can further be refined.

\section{ACKNOWLEDGEMENT}

Authors are thankful to our whole team for making this work possible. The authors are exceedingly thankful to Engr. Fida Hussain Siddiqui, and Engr. Moazzam Mughal, for their help during data collection. Finally, authors are thankful to Almighty Allah, who is ever graceful on us.

\section{REFERENCES}

[1] Afolayan, O.S., Ogundele, F.O., and Odewumi, S.G., "Hydrological Implication of Solid Waste Disposal on Groundwater Quality in Urbanized Area of Lagos State, Nigeria", International Journal of Applied Science and Technology, Volume 2, No. 5, pp. 74-82, 2012.

[2] Shrestha, M.E., Sartohadi, J., Ridwan, M.K., and Hizbaron, D.R., "Converting Urban Waste into Energy in Kathmandu Valley: Barriers and Opportunities”, Journal of Environmental Protection, Volume 5, No. 9, pp. $772-779,2014$.

[3] Pakistan Institute for Parliamentary Services, "Parliamentary Research Digest", Volume 4, March, 2017.

[4] Saxena, G., Chandra, R., and Bharagava, R.N., "Environmental Pollution, Toxicity Profile and Treatment Approaches for Tannery Wastewater and Its Chemical Pollutants", Reviews of Environmental Contamination and Toxicology, Volume 240, pp. 31-69, Springer International Publishing, 2016.

Mehran University Research Journal of Engineering \& Technology, Volume 37, No. 3, July, 2018 [p-ISSN: 0254-7821, e-ISSN: 2413-7219] 
[5] Brief on Solid Waste Management in Pakistan, available at www.waste.ccacoalition.org/sites/default/files/files/ brief-swm-_pak.pdf (Accessed on 2nd October, 2017).

[6]

Carl, R.B.,’Financing Solid Waste Management Projects in Developing Countries:Lessons from a Decade of World Bank Lending”, Proceedings of International Conference on Biological Treatment of Waste and the Environment, Rhombos, pp. 757-765, Berlin, September 2-4, 1999.

[7] PEPA, "Guideline for Solid Waste Management", June 2005 .

[8] Amasuomo, E., Tuoyo, O.J.A., and Hasnain, S.A., "Analysis of Public Participation in Sustainable Waste Management Practice in Abuja, Nigeria”, Environmental Management and Sustainable Development, Volume 4, No. 1, pp.180-193, 2015.

Gupta, R., and Misra, A.K., "Groundwater Fluoride in Haryana State: A Review on the Status and Its Mitigation", Study of Civil Engineering and Architecture, 2014.

[10] Kihampa, C., "Environmental Exposure and Public Health Concerns of Municipal Solid Waste Disposal in Dar Es Salaam, Tanzania, Sustainable Development, Volume 15, No. 3, pp. 198-208, Africa, 2013.

[1 1] Balasooriya, B.M.R.S., Vithanage, M., Nawarathna, N.J., Zhang, M., and Herath, G.B.B., "Solid Waste Disposal Site Selection for Kandy District, Sri Lanka Integrating GIS and Risk Assessment”, International Journal of Scientific and Research Publications, Volume 4, No. 10, pp. 1-6, October, 2014.
[12] Majeed, K., Adila, S.B., and Nawaz, M.C., "Economic Potential of Recycling Business in Lahore, Pakistan”, Waste Management, Volume 28, pp. 294, 2008.

[13] McAllister, J, "Factors Influencing Solid-Waste Management in the Developing World", Master of Science, Environment and Society, Utah State University, 2015

[14] Shekdar, A.V., "Sustainable Solid Waste Management: An Integrated Approach for Asian Countries", Waste Management, Volume 29, No. 4, pp. 1438-1448, 2009.

[15] Environment Protection Department, Government of Punjab, 2012 (Accessed at epd.punjab.gov.pk)

[16] Memon, A.H., Rahman, I.A., and Azis, A.A.A., "Preliminary Study on Causative Factors Leading to Construction Cost Overrun", International Journal of Sustainable Construction Engineering and Technology, Volume 2, No. 1. pp. 57-71, 2011.

[17] Korai, M.S., "Characterizing and Composting the Municipal Solid Waste of Hyderabad City", Master Thesis, Institute of Environmental Engineering \& Management, Mehran University of Engineering and Technology, Jamshoro, Sindh, Pakistan, 2009.

[18] Coelho, K., Kamath, L., and Vijaybaskar, V., "Interrogating Citizen Participation Mandates in Indian Urban Governance”, IDS Working Papers, Volume 362, pp. 1-33, 2011. 